\title{
What is Left of User Rights? - Algorithmic Copyright Enforcement and Free Speech in the Light of the Article 17 Regime
}

\author{
Sebastian Schwemer* and Jens Schovsbo ${ }^{\dagger}$
}

\begin{abstract}
Article 17 of the Directive on copyright and related rights in the Digital Single Market (the DSM Directive) has strengthened the protection of copyright holders. Moving forward, online content-sharing providers will be responsible for copyright infringement unless the use of works on their platforms is authorized or if they have made 'best efforts' to obtain an authorization and prevent the availability of unlicensed works. At the same time, the Directive has made it clear that users of protected works shall be able to rely on the existing limitations and exceptions regarding quotation, criticism and review and caricature, parody or pastiche. The Directive even casts these limitations and exceptions as user rights. This paper points out that copyright's limitations and exceptions have traditionally constituted a corner stone in the internal balancing of the interests of users against rights holders and with a clear view of safeguarding the interests of free expression and information protected by the Charter. Given the overall purpose of the DSM Directive in strengthening the position of rights holders, there is a dire risk that the benefits of the limitations and exceptions evaporate in the attempts of platform operators to escape liability by use of algorithmic enforcement. The article uses the recent decisions of the CJEU in Pelham, Funke Medien and Spiegel Online to draw attention to the central importance of the limitations and exception as the primary channel for fundamental rights analyses in copyright. It is finally pointed out how the DSM Directive - despite of its on-the-paper recognition of users' rights-is most likely going to lead to a devaluation of those same rights.
\end{abstract}

* Industrial PostDoc, Ph.D., Centre for Information and Innovation Law (CIIR), University of Copenhagen.

${ }^{\dagger}$ Professor, LL.D., Ph.D., Centre for Information and Innovation Law (CIIR), University of Copenhagen. 


\section{INTRODUCTION}

Article 17 of the Directive on copyright and related rights in the Digital Single Market ${ }^{1}$ (hereinafter 'DSM Directive') aims to strengthen the position of copyright holders vis-à-vis platform to fill an alleged value gap which has been argued to have arisen because of legal uncertainty and inefficient enforcement mechanisms. Seen from the perspective of fundamental rights, such an endeavour is in itself unproblematic or even laudatory: After all, the Charter of Fundamental Rights of the European Union's ' (hereinafter 'Charter') Article 17(2) recognizes copyright as a fundamental right itself and mechanisms which ensure that copyright functions as anticipated by the legislator should be hailed as a natural extension of the acceptance of the system in itself.

However, it is important to bear in mind that there is an intimate relationship between substantive law and enforcement mechanisms, or to phrase it more succinctly: between law as it appears in the books and law in action. As seen from such a perspective, legal analyses should include i.a. the institutional setting of the substantive law. This setting may either be 'too weak' in the sense that rights holders are not actually able to enforce their rights against users to the extent that the legislator has anticipated. Also, it may be 'too strong' in the sense that rights holders are able to overextend protection to claim more than their share e.g. by limiting user rights. Both positions - the former of 'under enforcement' and the latter of 'over enforcement' - are problematic.

It is our starting point for the following, that whereas Article 17 may be seen as a response to a problem of 'under enforcement', the role which online sharing platforms are supposed to play implies a risk of 'over enforcement'. ${ }^{3}$ These risks have been pointed out many times in the long and at times tumultuous process which led to the adoption of Article 17 and the debate is far from over. By way of example, just a week after the Directive had been published in the Official Journal, Poland brought an action under Article 263 TFEU against Article 17 before the Court of Justice seeking partial annulment. ${ }^{4}$ Specifically, the action is directed against the Article's provision regarding best efforts to ensure the unavailability unlicensed works as well as the prevention of re-uploads after takedowns respectively. ${ }^{5}$ The action is based on the Republic's view that the provision infringes the freedom of expression and the freedom of information guaranteed in Article 11 of the Charter. ${ }^{6}$ In a similar vein, in March 2019, the UN Special Rapporteur on the promotion and protection of the right to freedom of opinion and expression, David Kaye, criticized the provision for its incompatibility with human rights, noting that '[m]isplaced confidence in filtering technologies to make nuanced distinctions between copyright

\footnotetext{
${ }^{1}$ Directive (EU) 2019/790 on copyright and related rights in the Digital Single Market [2019] OJ L 130, pp. 92125.

${ }^{2}$ Charter of Fundamental Rights of the European Union [2012] OJ C 364, pp. 1-22.

${ }^{3}$ See in this context e.g. CJEU in C-360/10, Belgische Vereniging van Auteurs, Componisten en Uitgevers CVBA (Sabam) v Netlog, ECLI:EU:C:2012:85, para. 50, that measures 'could potentially undermine freedom of information, since that system might not distinguish adequately between unlawful content and lawful content.' ${ }^{4}$ Case C-401/19, Republic of Poland v European Parliament and Council of the European Union (2019/C $270 / 24)$, OJ C 270, p. 22. The Polish action is also to be seen against the national political background. The Directive's Article 17 has been a prominent topic in the general public and during national elections.

${ }^{5}$ Art. 17 (4)(b) and Art. 17 (4)(c), in fine.

${ }^{6}$ Interestingly, the Republic chose not to invoke the right to conduct business.
} 
violations and legitimate uses of protected material would escalate the risk of error and censorship'. ${ }^{7}$ Also, the German Minister of Justice, Katharina Barley, had expressed concerned about the compatibility of Article 17 with fundamental rights, but had given in to vote in favour. Germany, in its extensive statement accompanying its Council vote, noted that '[t]he aim must be to make the "uploadfilter" instrument largely superfluous. ${ }^{8}$ Going even further, this is substantiated by the Council vote, where The Netherlands, Luxembourg, Poland, Italy and Finland voted against the Directive due to concerns that 'the final text of the Directive fails to deliver adequately on the above-mentioned aims' and '[m]ost notably we regret that the Directive does not strike the right balance between the protection of right holders and the interests of EU citizens and companies. ${ }^{9}$ The scholarly community, too, has since early in the legislative process raised fundamental rights concerns in relation to the European Commission's proposal from September 2016 as well as the final text from May 2019. ${ }^{10}$ Senftleben, for example, criticizes the 'remarkable transformation of the function of copyright law ... [which] degenerates into a censorship and filtering instrument. ${ }^{, 11}$

In this contribution, we join the conversation. Article 17 addresses the triangular relation between rights holders, online content-sharing service providers (OCSSPs) and users. Much of the criticism is related to the Article's interface with the E-Commerce Directive's ${ }^{12}$ prohibition of general monitoring obligations ${ }^{13}$ and fundamental rights. Here, we are not addressing the principal- upstream question of compatibility of potential content filtering with fundamental rights. Instead, we focus on the relation between OCSSPs and the issues of freedom of expression, freedom of information and freedom of arts. More specifically, we focus on the role of copyright's limitations and exceptions in the scheme set up by Article 17. These provisions, which stem from the international copyright conventions where they are anchored in the three-

\footnotetext{
${ }^{7}$ UNHR, EU must align copyright reform with international human rights standards, says expert (11 March 2019), https://www.ohchr.org/EN/NewsEvents/Pages/DisplayNews.aspx?NewsID=24298\&LangID=E.

${ }^{8}$ Council of the European Union, Statement by Germany, (5 April 2019), point 8, https://data.consilium.europa.eu/doc/document/ST-7986-2019-ADD-1/en/pdf.

${ }^{9}$ Council of the European Union, Joint statement by the Netherlands, Luxembourg, Poland, Italy and Finland, (5 April 2019), https://data.consilium.europa.eu/doc/document/ST-7986-2019-ADD-1/en/pdf.

${ }^{10}$ See e.g. Sophie Stalla-Bourdillon et.al., Open Letter to the European Commission - On the Importance of Preserving the Consistency and Integrity of the EU Acquis Relating to Content Monitoring within the Information Society (September 30, 2016), https://ssrn.com/abstract=2850483; Martin Senftleben et al., The Recommendation on Measures to Safeguard Fundamental Rights and the Open Internet in the Framework of the EU Copyright Reform, 40 E.I.P.R. 3 (2018), pp. 149-163; Christina Angelopoulos, On Online Platforms and the Commission's New Proposal for a Directive on Copyright in the Digital Single Market, (January 2017), https://ssrn.com/abstract=2947800; João Quintais et al., Safeguarding User Freedoms in Implementing Article 17 of the Copyright in the Digital Single Market Directive: Recommendations From European Academics, (November 11, 2019), https://ssrn.com/abstract $=3484968$.

${ }^{11}$ Martin Senftleben, Bermuda Triangle - Licensing, Filtering and Privileging User-Generated Content Under the New Directive on Copyright in the Digital Single Market, (April 4, 2019), https://ssrn.com/abstract=3367219, p. 5.

${ }^{12}$ Directive 2000/31/EC of the European Parliament and of the Council of 8 June 2000 on certain legal aspects of information society services, in particular electronic commerce, in the Internal Market [2000] OJ L 178, pp. 1-16 (hereinafter the 'E-Commerce Directive' or 'ECD').

13 Art. 15 ECD.
} 
step-test, have traditionally constituted a centrepiece of copyright's internal safeguards of users' interests. In the following we revisit the limitations and exceptions ${ }^{14}$ in the light of Article 17, which has at the same time instituted a regime of algorithmic enforcement and bolstered the system of limitations and exceptions by recasting some of them as user rights and imposing procedural obligations on OCSSPs to safeguard those rights.

\section{THE REGIME OF ARTICLE 17}

\subsection{Introduction}

The background for Article 17 DSM Directive on the 'Use of protected content by online content-sharing service providers' is a peculiar one: the intermediary liability exemption rules of the E-Commerce Directive have allegedly led to a failure in the copyright market: ${ }^{15}$ based on the notice-and-takedown regime, online content sharing platforms have been argued to have enjoyed an unfair advantage when negotiating (music) licensing deals with rights holders. ${ }^{16} \mathrm{In}$ a nutshell, this very specific issue of a potential 'value gap' in relation to the use of musical works on platforms like Youtube ${ }^{17}$, is the context of Article 17.

According to Article 17(1) DSM Directive, Member States shall provide that an OCSSP performs an act of communication to the public or an act of making available to the public for the purposes of this Directive when it gives the public access to copyright-protected works or other protected subject matter uploaded by its users. ${ }^{18}$ In other words, affected services are directly liable for copyright infringements by user uploads. In these situations, the horizontal liability exemption rules are thrown overboard. ${ }^{19}$ Thus, affected platforms can no longer invoke Article 14 E-Commerce Directive for the copyright-relevant acts of their users and licensing

\footnotetext{
${ }^{14}$ The DSM Directive introduces several new limitations and exceptions. Given our focus on the specific Art. 17context, these are outside the scope of our contribution. Also, Article 25 DSM Directive on the relationship with exceptions and limitations provided for in other directives is outside the scope.

${ }^{15}$ It is notable that the question whether Youtube can be considered 'passive' and thus falls under the liability exemption rules of Art. 14 ECD, has only recently been subject to a reference to the CJEU, see case C-682/18, Youtube and case C-500/19, Puls 4 TV. Related question had previously been answered by the Court in Joined Cases C-236/08 to C-238/08, Google AdWords, ECLI:EU:C2010:159 at para. 107, and Case C-324/09 (eBay) ECLI:EU:C:2011:474, para. 113.

${ }^{16}$ See e.g. Stan Liebowitz, Economic Analysis of Safe Harbor Provisions (prepared for CISAC, February 27, 2018). See also the problem definition in the Commission's Impact Assessment: 'Rightholders have no or limited control over the use and the remuneration for the use of their content by services storing and giving access to large amounts of protected content uploaded by their users', European Commission, Commission Staff Working Document, Impact Assessment on the modernisation of EU copyright rules, Brussels, 14.9.2016 SWD (2016) 301 final, PART 1/3, p. 137 and p. 143.

${ }^{17}$ Effectively, the scope of Art. 17 is broader, though: 'online-content sharing service providers' (OCSSPs) defined in Art. 2 nr. 6 DSM Directive, likely also encompasses other platforms like Facebook, Slideshare (sharing of presentations), Pinterest (image sharing), Snapchat, Instagram, erotic streaming sites like Pornhub etc.

${ }^{18}$ The unclarity of what constitutes a communication to the public has also been identified as obstacle by Commission in European Commission, Towards a modern, more European copyright framework, COM(2015) 626 final, p. 9. On case law on communication to the public more broadly, see João Pedro Quintais, Untangling the hyperlinking web: In search of the online right of communication to the public, 21 J. World Intell. Prop. 5-6 (2018), pp. $385-420$.

${ }^{19}$ Art. 17(3) DSM Directive.
} 
becomes the legislative default option for the use of copyright-protected works in these situations, too. ${ }^{20}$

Instead of the traditional Article 14 E-Commerce Directive liability exemption regime for 'hosting $^{21}$, Article 17(4) stipulates the cumulative conditions under which an OCSSP is not liable for content uploaded by its users. ${ }^{22}$ Firstly, Article 17(4)( a) stipulates that affected services need to demonstrate their best effort to obtain licenses for user-uploaded content. This is the main trajectory foreseen by the Directive to achieve its goals. ${ }^{23}$ Secondly, according to Article 17(4)(b) DSM, affected services need also to have 'made, in accordance with high industry standards of professional diligence, best efforts to ensure the unavailability of specific works and other subject matter for which the rightholders have provided the service providers with the relevant and necessary information'. Thirdly, in any event, affected services need to have 'acted expeditiously, upon receiving a sufficiently substantiated notice from the rightholders, to disable access to, or to remove from their websites, the notified works or other subject matter, and made best efforts to prevent their future uploads in accordance with point (b)' according to Article $17(4)(\mathrm{c}){ }^{24}$

In this way it follows from Article 17 that it is the duty of OCSSPs to 'filter' unlicensed works and prevent their upload or re-upload. Compared to earlier versions in the legislative process, where technical means were directly mentioned, the final version of the Directive refrains from prescribing that the mechanism is implemented by using algorithmic solutions. Thus, there exists in fact no ex lege obligation for the affected parties to rely on algorithms. However, given the practical infeasibility of handling the large number of user uploads, the difficulty to identify previously blocked content without technical means, and the reference to 'high industry stand$\operatorname{ards}^{, 25}$, the use of such algorithmic solutions is likely, akin to a de facto imposition.

\footnotetext{
${ }^{20}$ On licensing, see Martin Husovec \& João Quintais, How to License Article 17? Exploring the Implementation Options for the New EU Rules on Content-Sharing Platforms, IViR Working Paper (1 October 2019), https://ssrn.com/abstract=3463011.

${ }^{21}$ Art. 14(1) E-Commerce Directive on hosting reads: 'Where an information society service is provided that consists of the storage of information provided by a recipient of the service, Member States shall ensure that the service provider is not liable for the information stored at the request of a recipient of the service, on condition that: (a) the provider does not have actual knowledge of illegal activity or information and, as regards claims for damages, is not aware of facts or circumstances from which the illegal activity or information is apparent; or

(b) the provider, upon obtaining such knowledge or awareness, acts expeditiously to remove or to disable access to the information.'

${ }^{22}$ On the one hand, Art. 17 (4) DSM Directive is somewhat awkward in the context of copyright, systematically it fits with much better within the E-Commerce Directive, where intermediary liability exceptions are horizontally addressed and to which Art. 17 is represents a sector-specific carve-out. On the other hand, Art. 17 (1) DSM Directive introduces a substantive right and Art. 17 (2) DSM Directive a limitation of that right.

${ }^{23}$ I.e. to 'foster the development of the licensing market between rightholders and ... .', see Recital 61 DSM Directive. See also Statement by Germany, supra note 8, para. 10, 'in the European compromise, licensing is the method chosen to achieve... .'

${ }^{24}$ Art. 17(5) specifies that 'best efforts' have to be 'proportionate', meaning that the concept should take into account the type and size of the service, the type of content, and the costs of rights clearance given the existing licensing options on the market.

${ }^{25}$ Youtube, for example, has had an algorithmic content regulation system, 'ContentID', in place since 2007. For an overview on content identification technologies, see Annex 12 in European Commission, Commission Staff Working Document, Impact Assessment on the modernisation of EU copyright rules, Brussels, 14.9.2016 SWD (2016) 301 final, PART 3/3, pp. 164-174.
} 
- DRAFT DECEMBER 2019

Forthcoming in Paul Torremans (ed), Intellectual Property Law and Human Rights, $4^{\text {th }}$ edition (Wolters Kluwer, 2020)

Outside this novel liability exemption scheme in Article 17(4) DSM Directive, the sharing of user uploads is given Article 17(1) DSM Directive thus only permissible if a) permission has been granted or b) the use is covered by a specific limitation or exception.

\subsection{Article 17's fundamental rights interface and limitations and exceptions}

The protection of intellectual property rights (IPR) is enshrined in Article 17(2) of the Charter where after 'Intellectual property shall be protected [as property]'. As it will be explained below on the 'constitutionalisation' of EU IPR, the Court of Justice of the European Union (CJEU) has established a reading where after IPRs are neither inviolable nor offer 'absolute protection'. ${ }^{26}$ Instead courts should balance the (property) rights of rights holders against the protection of other fundamental rights such as the protection of personal data and of private life (EU Charter Articles 7 and 8) and the freedom of expression and information (Charter Article $11)$.

Compared to earlier IP-related secondary EU legislation such as the InfoSoc Directive, fundamental rights are referenced explicitly in the DSM Directive. ${ }^{27}$ In recital 84 , for example, the DSM Directive stipulates broadly:

'This Directive respects the fundamental rights and observes the principles recognised in particular by the Charter. Accordingly, this Directive should be interpreted and applied in accordance with those rights and principles. ${ }^{28}$

In addition to the general acknowledgment of fundamental rights, the Directive comes with several specific references related to the Article 17-mechanism, notably in recital 70 (emphasis added):

'The steps taken by online content-sharing service providers in cooperation with rightholders should be without prejudice to the application of exceptions or limitations to copyright, including, in particular, those which guarantee the freedom of expression of users. Users should be allowed to upload and make available content generated by users for the specific purposes of quotation, criticism, review, caricature, parody or pastiche. That is particularly important for the purposes of striking a balance between the fundamental rights laid down in the Charter of Fundamental Rights of the European Union ('the Charter'), in particular the freedom of expression and the freedom of the arts, and the right to property, including intellectual property. Those exceptions and limitations should, therefore, be made mandatory in order to ensure that users receive uniform protection across the Union. It is important to ensure that

\footnotetext{
${ }^{26}$ See Case C-70/10, Scarlet Extended SA v Société belge des auteurs, compositeurs et éditeurs SCRL (SABAM), ECLI:EU:C:2011:771, para. 43. See also the EU Charter Art. 17(1) in fine which makes it clear that the 'use of property may be regulated by law in so far as is necessary for the general Interest protection'. This also applies to IPR.

${ }^{27}$ Since the Lisbon Treaty, also other recent secondary legislation unrelated to IP, acknowledges fundamental rights and more specifically the freedom of expression, see e.g. recitals 16 and 48 of Directive 2010/13/EU on the coordination of certain provisions laid down by law, regulation or administrative action in Member States concerning the provision of audiovisual media services [2010] OJ L 95, pp. 1-24 (Audiovisual Media Services Directive) and recital 153 of Regulation (EU) 2016/679 on the protection of natural persons with regard to the processing of personal data and on the free movement of such data, and repealing Directive 95/46/EC (General Data Protection Regulation) [2016] OJ L 119, pp. 1-88.

${ }^{28}$ And in the same wording already in the Commission's proposal from September 2016, see European Commission, Proposal for a Directive on copyright in the Digital Single Market, COM/2016/0593 final - 2016/0280 (COD), (Brussels, 14.9.2016), recital 45.
} 
Compared to the Commission's Proposal from September 2016, this constitutes a significant strengthening of user rights. In its Explanatory Memorandum, the Commission commented on the improved bargaining situation of rightsholders and noted that 'the Directive has a limited impact on the freedom to conduct a business and on the freedom of expression and information, as recognised respectively by Articles 16 and 11 of the Charter, due to the mitigation measures put in place and a balanced approach to the obligations set on the relevant stakeholders. ${ }^{29}$

The most distinct feature relates to this latter point, namely the balancing within Article 17 (7) and (9), which has only been introduced relatively late in the legislative process. As it has already been explained above, under the DSM Directive, sharing of user uploads is only permissible if a) permission has been granted or b) if the use is covered by a specific limitation or exception. Additionally, Article 17 (7) stipulates:

\begin{abstract}
'The cooperation between online content-sharing service providers and rightholders shall not result in the prevention of the availability of works or other subject matter uploaded by users, which do not infringe copyright and related rights, including where such works or other subject matter are covered by an exception or limitation.
\end{abstract}

Member States shall ensure that users in each Member State are able to rely on any of the following existing exceptions or limitations when uploading and making available content generated by users on online content-sharing services:

quotation, criticism, review;

use for the purpose of caricature, parody or pastiche'

As it can be seen (cf. the word 'shall'), the exceptions or limitations regarding quotation, criticism, review and use for the purpose of caricature, parody or pastiche, which we know from the InfoSoc Directive, are mandatory in the sense that Member States shall ensure that users are able to rely on them. ${ }^{30}$ Whereas it has been argued previously in the literature by Geiger that the CJEU had already in earlier decisions provided for (substantive) 'users right's ${ }^{31}$, it is quite remarkable that recital 70 makes the point so clear. ${ }^{32}$

\footnotetext{
${ }^{29}$ Ibid., Explanatory Memorandum, p. 9. See also European Commission, supra note 16, pp. 154-155, noting that '[t]he freedom of expression and information may be affected negatively in cases where the services limit user uploaded content in an unjustified manner (for example when an exception or a limitation to copyright applies or the content is in public domain) or when the technologies fail to identify the content correctly.'

${ }^{30}$ It has been suggested that the concepts (quotation: Art. 5(3)(d) InfoSoc Directive; caricature, parody or pastiche: Art. 5(3)(k) InfoSoc Directive) in Art. 17(7) should be considered autonomous EU concepts which are to be interpreted consistently across the directives and in line with CJEU case law, see João Quintais et al., supra note 10.

${ }^{31}$ Christophe Geiger and Elena Izyumenko, The Constitutionalization of Intellectual Property Law in the EU and the Funke Medien, Pelham and Spiegel Online Decisions of the CJEU: Progress, But Still Some Way to Go!, Centre for International Intellectual Property Studies (CEIPI) Research Paper No. 2019-09, (21 October 2019), p. 10 ff.; Senftleben, supra note 11, p. 8, more critically, notes that "the scope of this obligation and the consequences of insufficient support for relevant copyright limitations remain unclear. The expression "are able to rely on" need not be understood in the sense of a hard obligation to ban filter systems that are incapable of distinguishing between a permissible parody and an infringing copy.'

${ }^{32}$ In relation to consumer rights, it has been noted that 'consumers remained largely off copyright law's radar screen', see Bernt Hugenholtz \& Natali Helberger, No Place Like Home for Making a Copy: Private Copying in European Copyright Law and Consumer Law, 22 Berkeley Technology Law Journal 1061 (2007), p. 1077. In 2014,
} 
Apart from strengthening the specific limitations and exceptions by casting them as user rights, Article 17 also contains procedural safeguards of these rights, which we explore in depth below. OCSSP's are thus obliged to support users when they engage in quotation etc., see recital 70. Additionally, platforms are required to inform users in their terms and conditions of the user's right to use works under exceptions or limitations. ${ }^{33}$

\subsection{The role of limitations and exceptions in the light of the case law of the CJEU}

In order to understand the background to the Directive we now turn to the case law of the CJEU on the interface between copyright and fundamental rights and the 'constitutionalisation $^{34}$ of EU IPR. The literature on this topic is abundant and here we focus just on the most recent developments (namely Pelham, Funke Medien and Spiegel Online). Suffice therefore to note that following the decisions from the CJEU in Promusicae ${ }^{35}$, Scarlet Extended, ${ }^{36}$ UPC Telekabe ${ }^{37}$ and Deckmyn ${ }^{38}$, the Court had established a balancing of interests as the central mechanisms for the 'constitutionalisation' of IPR. ${ }^{39}$ Unlike in a traditional IPR analysis, the constitutional balancing uses the -as seen form a copyright perspective- external norms and values of fundamental rights' norms to interpret copyright law. As seen in this perspective, the weight on the rights holder's side of the scale is provided by the right to property. On the other side of the scale, one might find the rights to freedom of expression and information. The nature of the interests and their weights cannot, however, be gauged once and for all but must be determined through a case-by-case analysis. The test is based on a principle of neutrality (no 'absolute protection of IPR') and it's open-endedness lies at the very heart of the test and enables court to draw on arguments found outside of the IPR framework and well-established basic assumptions (the 'author-centeredness of copyright'). ${ }^{40}$ These position now have to be reevaluated in the light of the most recent developments in the case law from the CJEU.

\footnotetext{
the copyright unit within the European Commission was moved from its traditional proximity to other property rights in DG MARKT to the DG CONNECT, meaning a closer proximity to units working on Internet- and internal market related aspects, see Sebastian Felix Schwemer, Licensing and Access to Content in the European Union, (Cambridge University Press 2019), pp. 15-16.

${ }^{33}$ Art. 17(9) para. 4 DSM Directive.

${ }^{34} \mathrm{See}$ on the term 'constitutionalisation' the foundational paper Christophe Geiger, 'Constitutionalising' Intellectual Property Law? The Influence of Fundamental Rights on Intellectual Property in the European Union, International Review of Intellectual Property and Competition Law (2006) 37(4), pp. 371-406.

${ }^{35}$ Case C-275/06, Productores de Música de España (Promusicae) v Telefónica de España SAU, ECLI:EU:C:2008:54.

36 Supra, note 26.

${ }^{37}$ Case C-314/12, UPC Telekabel Wien GmbH v Constantin Film Verleih GmbH and Wega Filmproduktionsgesellschaft mbH, ECLI:EU:C:2014:192.

${ }^{38}$ Case C-201/13, Johan Deckmyn and Vrijheidsfonds VZW ${ }_{v}$ Helena Vandersteen and Others, ECLI:EU:C:2014:2132.

${ }^{39}$ On the 'fair balance' doctrine, see e.g. Christina Angelopoulos \& Stijn Smet, Notice-and-fair-balance: how to reach a compromise between fundamental rights in European intermediary liability, Journal of Media Law, 8:2 (2016), pp. 266 ff.

${ }^{40}$ Based on Jens Schovsbo, "Mark My Words"_Trademarks and Fundamental Rights in the EU, 8 U.C. Irvine L. Rev. 555 (2018).
} 


\subsubsection{Pelham ${ }^{41}$, Funke Medien $^{42}$ and Spiegel Online ${ }^{43}$}

The three judgments were handed down on the same day (29 July 2019) by the Great Chamber and all were based on Opinions from Advocate General (AG) M. Szpunar. The facts of the 'trinity' of cases are quite diverse: Pelham (or Metall auf Metall case) concerned the sampling of a piece of music composed by the German band 'Kraftwerk' ${ }^{44}$; Funke Medien dealt with the right to use allegedly copyright protected 'parliament briefings' ('the Afghanistan papers'); and Spiegel Online with hyperlinking to copyright protected material as part of the reporting by a media outlet. However, the answers in all cases had to be found in the intersection between national and EU copyright and fundamental rights law.

As seen from the perspective of this contribution, the central aspect of the judgments was the way the CJEU limited the freedom of national courts to rely on the Charter to go 'outside' of the catalogue of exceptions established by the InfoSoc Directive. By way of example in Funke Medien, the Court stated that the freedom of information and freedom of the press, enshrined in Article 11 of the Charter, 'are not capable of justifying, beyond the exceptions or limitations provided for in Article 5(2) and (3) of [the InfoSoc Directive], a derogation from the author's exclusive rights of reproduction and of communication to the public, referred to in Article 2(a) and Article 3(1) of that directive respectively.' In other words: The fair balancing between creators' interests and users' interests, which lies at the core of the 'constitutionalisation', has been internalized via the limitations and exceptions. It is in interpreting those provisions that courts may draw on various legal sources e.g. fundamental rights. In this way, one can describe the decision as leaving the door open to the constitutionalisation but also making clear that the constitutional door only gives way to a room which has been built according to the blueprint found in the InfoSoc Directive.

When it comes to the interpretation of the limitations and exceptions themselves, the freedom of Member States depends on the wording of the individual provisions. Even if some discretion is left to national courts, however, the CJEU in Funke Medien made it clear that such freedom would often be (even at some points 'highly) 'circumscribed' in several regards (paras. $45 \mathrm{ff}$.) e.g. by 'the general principles of EU law, which include the principle of proportionality, from which it follows that measures which the Member States may adopt must be appropriate for attaining their objective and must not go beyond what is necessary to achieve it' (para. 49). Also Member States cannot rely on any discretion enjoyed by them according to a directive so as to 'compromise the objectives of that directive' (para. 50). At the same time, however, Member States must make sure that the effectiveness of the exceptions and limitations is safeguarded and a fair balance of rights and interests between the different categories of rights holders, as well as between the different categories of rightholders and users of protected subject matter, is secured (para. 51). Furthermore, a fair balance must to be struck between the various

\footnotetext{
${ }^{41}$ Case C-476/17, Pelham GmbH and Others v Ralf Hütter and Florian Schneider-Esleben, ECLI:EU:C:2019:624.

${ }^{42}$ Case C-469/17, Funke Medien NRW GmbH v Bundesrepublik Deutschland, ECLI:EU:C:2019:623.

${ }^{43}$ Case C-516/17, Spiegel Online GmbH v Volker Beck, ECLI:EU:C:2019:625.

${ }^{44}$ The original Kraftwerk song can be accessed here: https://www.youtube.com/watch?v=JlatOPOMlyA. The sampling song "Nur mit Dir" here: https://www.youtube.com/watch?v=_KQLxP-UX_Y. In the national German Metall auf Metall saga and music sampling see also Bernd Justin Jütte and Henrike Maier, A human right to sample-will the CJEU dance to the BGH-beat?, Journal of Intellectual Property Law \& Practice (2017), pp. 784796.
} 
fundamental rights protected by the European Union legal order (para. 53). Importantly even the 'three-step-test' in InfoSoc Directive Article 5(5) -which here serves to limit the effect of the limitations- is seen as constituting an element of the overall fair balancing (para. 61).

The effectiveness of limitations and exceptions depends not just on their exact wording but also on the willingness of national courts to consider the conditions for the application to be fulfilled. As seen from a traditional and dogmatic view, Kur has pointed out that there is a 'normative drag' from IPR's inner structure and hierarchy of norms and interests that, so to speak, compels a narrow interpretation of limitations and limitations. ${ }^{45}$ Such an interpretation of course limits the impact of the limitations and exceptions and would as seen from a normative perspective furthermore stress the secondary importance of users' interests vis-à-vis those of rights holders. It has been argued that as seen from a 'constitutional' (and thus 'neutral') starting point one would need to give up on any presupposed modality for the interpretation of limitations and exceptions: If users' interests in access are as highly ranking as rights holders' interests in protection, then the baseline for establishing which is the 'main rule' - 'freedom of information' or 'exclusivity' - has evaporated and one is left with empty scales and a balancing of interests. ${ }^{46}$ In such a situation, one cannot a priori indicate whether to interpret the norm favouring users or authors 'narrowly' (or 'broadly'). ${ }^{47}$

The CJEU has on several occasions made it clear that limitations and exceptions should be interpreted narrowly based on what we called a 'traditional and dogmatic' argumentation above. $^{48}$ The Court revisited the issue in Funke Medien where it was asked to consider whether (as the Court decided to frame the question) a national court may under certain circumstances 'depart from a restrictive interpretation of [an exception] in favour of an interpretation which takes full account of the need to respect freedom of expression and freedom of information, enshrined in Article 11 of the Charter' (para. 65). In answering that question, the Court first remarks that 'is certainly the case, as the referring court notes, that any derogation from a general rule must, in principle, be interpreted strictly' (para. 89). This reconfirms the starting point of strict interpretation of limitations and exceptions. It is only against this backdrop that

\footnotetext{
${ }^{4}$ See in particular Annette Kur, Limitations and exceptions under the three-step test - how much room to walk the middle ground?, pp. 208-261 in: Annette Kur and Marianne Levin, Intellectual Property Rights in a Fair World Trade System - Proposals for Reform of TRIPS, (Edward Elgar 2011), pp. $212 \mathrm{ff}$.

${ }^{46}$ See Christophe Geiger et al., Limitations and Exceptions as Key Elements of the Legal Framework for Copyright in the European Union - Opinion on the Judgment of the CJEU in Case C-201/13 Deckmyn, International Review of Intellectual Property and Competition Law (2015) 46(3), 93-101, point 23-27; Jonathan Griffiths, Taking power tools to the acquis - the Court of Justice, the Charter of Fundamental Rights and European Union copyright law, pp. 144-174 in Christophe Geiger, Craig Allen Nard and Xavier Seuba, Intellectual property and the Judiciary (Edward Elgar, 2018), and Jens Schovsbo, Constitutional Foundations and Constitutionalization of IP Law - A Tale of Different Stories?, [2015] ZGE/IPJ 7 383, p. 391.

${ }^{47}$ This view is even supported by the case law of the European Court of Human Rights in Ashby Donald v. France App No. 36796/08 (ECtHR 2013), which according to Thom Snijders and Stijn van Deusen, The Road Not Taken - the CJEU Sheds Light on the Role of Fundamental Rights in the European Copyright Framework a Case Note on the Pelham, Spiegel Online and Funke Medien Decisions, IIC (2019) 50, pp. 1176-1190, p. 1185 'frames copyright enforcement measure in general as derogations from the freedom of information and freedom of expression' and as such open to external scrutiny via Art. 10 ECHR.

${ }^{48}$ E.g. C-527/15, Stichting Brein v Jack Frederik Wullems, ECLI:EU:C:2017:300, paras. 62 f. and C-265/16, VCAST Limited v RTI SpA, ECLI:EU:C:2017:913, paras. 31 f. See also C-435/12, ACI Adam BV and Others $v$ Stichting de Thuiskopie and Stichting Onderhandelingen Thuiskopie vergoeding, ECLI:EU:C:2014:254, paras. 20 ff.
} 
the Court states that even the limitations and exceptions could be said to 'confer rights on the users of works or of other subject matter' (para. 70). Also those rights, however, should be balanced in a fair manner against 'the rights and interests of rights holders, which must themselves be given a broad interpretation' (ibid.). Having thus established narrowness as the principle of interpretation for limitations and exceptions and broadness as the principle for the rights and interests of rights holders, the Court concludes that the interpretation of the exceptions and limitations involved in the case must allow 'their effectiveness to be to safeguarded and their purpose to be observed' in order 'to ensure observance of fundamental freedoms' (para. 71).

In this way the Court would seem to assume the traditional hierarchal view on the interests of rights holders at the top and users' interest below. Thus, even though the Court apparently accepts that sometimes conflicts between IPR and fundamental rights may occur, one should -when within the copyright system- assume that priority has been given to the exclusionary powers of rights holders at the immediate expense of users. This is the baseline, and that position, which constitutes copyright's pièce de résistance, cannot be challenged on the basis of the Charter. ${ }^{49}$

Arguably these remarks, which seem to diminish the role and function of the limitations and exceptions and to subscribe to the traditional and dogmatic perception of copyright as being a system 'for the protection of rights holders', are not easy to align with the statements that the limitations and exceptions aim at securing an overall fair balance (above) and with the conceptualization of limitations and exceptions as user rights. ${ }^{50}$

\subsubsection{Summing up}

At the same time that the Court canonised the inclusion of fundamental rights to copyright's internal analyses, it also gave a kiss of death to any attempts to rely on fundamental rights analyses to provide for an external system of checks and balances to be used to e.g. expand or substitute the predefined system of copyright protection or to deviate from the settled practice of a narrow interpretation of limitations and exceptions.

In this way, and as pointed out by Geiger and Izyumenko, the judgments emphasize the central function of limitations and exceptions to the overall balancing of fundamental rights concerns into the copyright analyses. ${ }^{51}$ The judgements primarily achieves this in two ways:

Firstly, the CJEU states that the limitations in Article 5 of the InfoSoc Directive 'confer rights of the users of works or other subject matter ${ }^{52}$ : limitations and exceptions, in other words, constitute user rights. What the Court had hinted at in earlier decision is here being unfolded.

\footnotetext{
${ }^{49}$ On this central point the CJEU may be on collision course with the ECtHR, see ECtHR, 10 January 2013 , Ashby Donald and Others v. France, CE:ECHR:2013:0110JUD003676908 and to this point Geiger \& Izyumenko, supra note 31, p. 26. This might also be the view of AG Spuznar in Funke Medien, see point 40: 'However, there may be exceptional cases where copyright, which, in other circumstances, could quite legitimately enjoy legal and judicial protection, must yield to an overriding interest relating to the implementation of a fundamental right or freedom.'

${ }^{50}$ Geiger \& Izyumenko, supra note 31, pp. $20 \mathrm{f}$.

${ }^{51}$ Ibid., p. 6.

${ }^{52}$ Funke Medien, supra note 42, para. 70, and Spiegel Online, supra note 43, para. 54.
} 
The decisions anchor the limitations and exceptions from the InfoSoc Directive rules on the use by the press (Article 5(3)(c)) and quotation for criticisms and review (Article 5(3)(d)) directly in the Charter. Arguably, Article 17 DSM Directive has already anticipated this development by making it clear that the specific limitations concerning quotation, criticism, review, caricature, parody or pastiche are mandatory ('unwaiveable'), see above.

Secondly, the importance of limitations and exceptions is underlined by the Court's rejection of the use by national courts of fundamental rights as external balancing tools. The Court thus makes it clear that it is the Directive that in an exhaustive way indicates the pathway for finding a 'fair balance between, on the one hand, the interest of the holders of copyright and related rights in the protection of their intellectual property rights and, on the other hand, the protection of the interests and fundamental rights of users of protected subject matter as well as of the public interest. ${ }^{, 53}$ Therefore, the full lifting of the fundamental rights interests and concerns has to be done by the internal balancing tools i.e. limitations and exceptions.

\section{PROCEDURAL SAFEGUARDS OF LIMTTATIONS AND EXCEPTIONS}

Besides the copyright-internal balancing system of limitations and exceptions, Article 17 DSM Directive also foresees an institutionalized system of checks and balances in form of procedural safeguards. These mechanisms do not concern substantive copyright, but rather its exercise and are foreseen at several levels: (1) at the platform level, (2) at the out-of-court level, and (3) at the judicial authority or court level.

At the platform level, Member States are in Article 17(9) DSM Directive mandated to provide that 'online content-sharing service providers put in place an effective and expeditious complaint mechanism that is available to users of their services in the event of disputes over the disabling of access to, or the removal of, works or other subject matter uploaded by them. ${ }^{54}$ The mechanisms of this first procedural safeguard are further circumscribed in Article 17(9) para. 2 DSM Directive, where after complaints 'shall be processed without undue delay, and decisions to disable access to or remove uploaded content shall be subject to human review. ${ }^{, 55}$ Especially the latter human review-criterion is interesting, as it implies that everything leading up to a dispute can be processed by the platform in an automated fashion by algorithms. ${ }^{56} \mathrm{It}$ is further specified in recital 70, that these mechanisms should allow 'users to complain about the steps taken with regard to their uploads, in particular where they could benefit from an exception or limitation to copyright in relation to an upload to which access has been disabled

\footnotetext{
${ }^{53}$ Pelham, supra note 41, para. 59, no identical wording in Funke Medien, supra note 42, but see para. 57 and also para. 74 (with reference to Ashby Donald and Others v. France and on this supra note 49).

${ }^{54}$ Emphasis added. Note that the requirement is on Member States, compared to the ensuring of unavailability which is on the platforms. This first aspect resembles the Commission's original proposal from September 2016, where it suggested in Art. 13(2) that 'Member States shall ensure that the service providers ... put in place complaints and redress mechanisms that are available to users in case of disputes over the application of the measures ... $\therefore$, see European Commission, supra note 28.

55 Emphasis added. On a critique of the 'elastic timeframe' see Senftleben, supra note 11, p. 9. In its Council vote, Germany suggests the timeframe to be understood 'as rapidly as possible', see Statement by Germany, supra note 8 , point 7.

${ }^{56}$ See similarly Commission Recommendation (EU) 2018/334 of 1 March 2018 on measures to effectively tackle illegal content online, 6.3.2018, [2018] L 63/50, points 20 and 27 in relation to proactive measures on human oversight and in the context of data protection see e.g. Art. 22 (3) GDPR.
} 
or that has been removed' (emphasis added). Furthermore, the provision stipulates a justification-duty on rights holders. The reasons for a rights holder's request to make content unavailable needs to be 'duly justified' ${ }^{57}$ The decision at this level remains with the platform, but as Senftleben notes, ' $[\mathrm{t}$ ]he underlying legal assessment, however, is likely to be cautious and defensive ... [and] a generous interpretation of copyright limitations serving freedom of expression seems unlikely, even though a broad application of the right of quotation and the parody exemption would be in line with CJEU jurisprudence. ${ }^{58}$ In other words, there exists a risk of over enforcement. ${ }^{59}$

In addition to the platform-based procedural safeguards, also out-of-court redress mechanisms for the impartial settlement of disputes are to be put in place by Member States. ${ }^{60}$ Finally, this out-of-court mechanism is 'without prejudice to the rights of users to have recourse to efficient judicial remedies ... . ${ }^{61}$ Specifically in relation to exceptions and limitations, 'Member States shall ensure that users have access to a court or another relevant judicial authority to assert the use of an exception or limitation to copyright and related rights. ${ }^{62}$ Member States enjoy a considerable amount of discretion when implementing the procedural safeguards and such mechanisms might also be informed by the stakeholder dialogues and the Commission's guidance on the application of Article $17 .{ }^{63}$

Conceptually, it is unclear whether these procedural safeguards should be understood as independent additions to the limitation and exception safeguards or rather as a further specification of those safeguards. Recital 70 of the DSM Directive puts Article 17(9) in the context of situations where 'in particular [users] could benefit from an exception or limitation' (emphasis added). Thus, one the one hand, the existence of these specific procedural safeguards relating to the institutional setting can be interpreted as an admirable attempt to create procedural transparency and safeguards. Without such setup, user rights might end up under- or even unenforced. The existing regime under the E-Commerce Directive does not directly put any restrictions on platforms on what content they remove. Seen in a broader European intermediary liability exemption perspective, where the notice-and-takedown regime based on Article

\footnotetext{
57 Art. 17(9) para. 2 DSM Directive.

${ }^{58}$ Senftleben, supra note 11, p. 9.

${ }^{59}$ For empirical work on over-enforcement see e.g. Kris Erickson \& Martin Kretschmer, Empirical approaches to intermediary liability, CREATe Working Paper 2019/6, (2019), p. 10 ff.; Jennifer Urban, Joe Karaganis, \& Brianna Schofield, Notice and Takedown: Online Service Provider and Rightsholder Accounts of Everyday Practice, 64 J Copyright Soc'y (2017); Sharon Bar-Ziv and Niva Elkin-Koren, Behind the Scenes of Online Copyright Enforcement: Empirical Evidence on Notice \& Takedown, 50 Connecticut Law Review (2017); specifically in the context of YouTube and parodies, see Kris Erickson \& Martin Kretschmer, This Video is Unavailable: Analyzing Copyright Takedown of User-Generated Content on YouTube, 9 JIPITEC 75 (2018) and Sabine Jacques et al., An Empirical Study of the Use of Automated Anti-Piracy Systems and Their Consequences for Cultural Diversity, 15(2) SCRIPTed (2018), pp. 277-312.

${ }^{60}$ Art. $17(9)$ para. 2 DSM Directive.

61 Ibid.

${ }^{62}$ Art. 17(9) para. 2 DSM Directive.

${ }^{63}$ Art. 17(10) DSM Directive reads: 'As of 6 June 2019 the Commission, in cooperation with the Member States, shall organise stakeholder dialogues to discuss best practices for cooperation between online content-sharing service providers and rightholders. ... When discussing best practices, special account shall be taken, among other things, of the need to balance fundamental rights and of the use of exceptions and limitations. For the purpose of the stakeholder dialogues, users' organisations shall have access to adequate information from online content-sharing service providers on the functioning of their practices with regard to paragraph 4' (emphasis added).
} 
14 of the E-Commerce Directive has lacked a counter-notice idea or general procedural safeguards, such attempt is to be welcomed and strengthening the enforcement of user rights visà-vis content moderation practices by large online platforms. On the other hand, however, their very existence implies an understanding of Article 17(7) that the mechanisms foreseen in Article 17(4) DSM Directive will inevitably lead to false-positives, i.e. to situations where platforms will falsely take-down or block content which is covered by a limitation or exception. ${ }^{64}$ In other words, it can also be understood as a confession that -in practice- automatically distinguishing copyright violations from legitimate uses will be a challenging exercise.

At least from the lawmaker's perspective, procedural safeguards in themselves are seen as a means of mitigating negative impact on fundamental rights. Already the Commission's Impact Assessment accompanying the Proposal from 2016, for example, noted that procedural safeguards will mitigate the negative impact on freedom of expression and information. ${ }^{65}$ Similarly, Germany in its Statement accompanying its Council vote notes that "[e]ach permanent "stay down" mechanism ("uploadfilter") must comply with the principle of proportionality. Procedural guarantees, in particular, could be considered, for example when users notify that they are lawfully uploading content from third parties. ${ }^{66}$ In other words, the procedural safeguards are in itself a weight on the scale of the fundamental rights balance.

\section{CONCLUDING REMARKS: WHAT IS LEFT OF USER RIGHTS?}

The limitations and exceptions contained in Article 5 InfoSoc Directive constitute user rights and courts are obliged to interpret those in the light of fundamental rights norms. In relation to these user rights, as seen, the DSM Directive's Article 17 contains both an internalized system of checks and balances with limitations and exceptions and a somewhat externalized system of procedural safeguards. For the specific limitations and exceptions consisting of 'quotation, criticism, review, caricature, parody or pastiche', the DSM Directive has made it clear that these are unwaivable and also that OCSSP's are under a specific obligation to safeguard those. The Commission's proposal for the Directive from September 2016 did not contain the reference to limitations and exceptions and neither procedural safeguards to the same extent as the final provision in the DSM Directive from May 2019. Previously optional limitations and exceptions from the InfoSoc Directive are fully harmonized within the Article 17-framework. And both, internalized and externalized safeguards, act as an expression of user rights as a balancing factor in the reconciliation of fundamental rights. But do these safeguards enough to balance the tensions between conflicting fundamental rights?

On a more principal level, a first aspect relates to a more upstream issue of the Article 17 mechanism. Both strands of safeguards, limitations and exceptions as well as procedural safeguards, come in at a relatively late stage. However, neither address the one very central upstream- challenge of Article 17 from a fundamental rights perspective: the de lege reliance

\footnotetext{
${ }^{64}$ In the Council vote, Germany lays outs its reading of Art. 17(7) and (8) 'that protective measures must not impede the permitted use of protected content', see Statement by Germany, supra note 8, point 7 . To this point see also European Commission, Impact Assessment, supra note 16, pp. $153 \mathrm{ff}$.

${ }^{65}$ European Commission, Impact Assessment, supra note 16, pp. 153-154, reading ' $[\mathrm{t}$ ] his negative impact should be mitigated by the fact that the services would be obliged to put in place the necessary procedural safeguards for the users which in the majority of cases already exist in the related context of notice and take down requests.'

${ }^{66}$ Statement by Germany, supra note 8, point 8.
} 
onstay down mechanisms and de facto reliance on filtering algorithms in the first place. ${ }^{67} \mathrm{As}$ Elkin-Koren points out: 'Algorithmic copyright enforcement has tilted the balance of copyright law. It has changed copyright default: if copyrighted materials were once available unless proven to be infringing, today materials that are detected by algorithms are removed from public circulation unless explicitly authorized by the right holder. ${ }^{68}$ This more principal issue is not directly dealt with by the two - downstream- safeguards we have addressed in this contribution. Instead, a third user-oriented safeguard is coming into play with Article 17(8), where it is stipulated in a somewhat declaratory fashion that the application of Article 17 DSM Directive may not lead to any general monitoring obligation. This prohibition of general monitoring contained in Article 15 E-Commerce Directive ${ }^{69}$ is again to be seen as a result of a balancing between fundamental rights (in particular Articles 7 and 8, 9, 10, and 14 of the Charter). ${ }^{70}$ Could an explanation be that the balancing of interests in limitations and exceptions is somehow relevant 'upstream' and 'overrides' or already contains the balancing of conflicting fundamental rights in relation to Article 15 E-Commerce Directive, too?

To further explore this argument, let us take one step back from the specific copyright system for a moment: The takedown of unlawful (or even unwanted) content has become topical in relation to a variety of subject matter such as hate speech $^{71}$, terrorist content and others. In this development, there is a call for 'enhanced responsibility'. ${ }^{72}$ In the Commission's Recommendation (EU) 2018/334, proactive -i.e. algorithmic content- mechanisms, akin the one introduced in Article 17 of the DSM Directive, are subject to a variety of safeguards and considerations. ${ }^{73}$ Similarly, also the Commission's proposal for a Regulation on Terrorist Content ${ }^{74}$, compared to Article 17 DSM Directive, is much more reluctant as to the instances when intermediaries should rely on proactive mechanisms in the first place. ${ }^{75}$ The DSM Directive, on the

\footnotetext{
${ }^{67}$ On the issue of notice and stay-down in relation to freedom of expression, see e.g. Jennifer M. Urban, Joe Karaganis, \& Brianna L. Schofield, Notice and Takedown in Everyday Practice, UC Berkeley Public Law Research Paper No. 2755628 (2016). On the applicability and compliance of the Commission's proposed Art. 13 in relation to notice and stay-down with Art. 8 and 10 of the ECHR, see Felipe Romero-Moreno, 'Notice and staydown' and social media: amending Article 13 of the Proposed Directive on Copyright, International Review of Law, Computers \& Technology, (2019), 33:2, pp. 187-210, p. 194 f.

${ }^{68}$ Niva Elkin-Koren, Fair Use by Design, UCLA Law Review 64 (2017), pp. 1082-1100, p. 1093.

${ }^{69}$ The prohibition of general monitoring in Art. 15 ECD has been subject to a surprisingly low number of references before the Court of Justice. In a case unrelated to IP rights, the Court of Justice recently ruled that platforms can be ordered to remove information that is 'identical' or 'equivalent' to content which is declared unlawful, see case C-18/18 Glawischnig-Piesczek v. Faebook Ireland Limited, [2019] ECLI:EU:C:2019:821, para. 53.

${ }^{70}$ In Scarlet v Sabam, supra note 26, and Sabam v Netlog, supra note 3, for example, the Court of Justice refers to the right to protection of personal information (Art. 8 of the Charter) and the freedom to receive or impart information (Art. 11 of the Charter).

${ }^{71}$ On the freedom of expression and hate speech, see Federica Casarosa, Freedom of Expression and Countering Hate Speech, Handbook on the Techniques of Judicial Interactions in the Application of the EU Charter, European University Institute, (2019).

${ }^{72}$ European Commission, Communication on Tackling Illegal Content Online - Towards an enhanced responsibility of online platforms, $\mathrm{COM}(2017) 555$ final, (Brussels, 28.9.2017).

${ }^{73}$ See e.g. Commission Recommendation (EU) 2018/334, supra note 56, points 19 and 20.

${ }^{74}$ On the proposed Terrorist Content Regulation, see also Alexandra Kuczerawy, The proposed Regulation on preventing the dissemination of terrorist content online: safeguards and risks for freedom of expression, CiTiP (5 December 2018).

${ }^{75}$ See Thomas Riis \& Sebastian Felix Schwemer, Leaving the European Safe Harbor, Sailing Towards Algorithmic Content Regulation, 22 Journal of Internet Law 7, (2019), pp. 12-16.
} 
other hand, offers little discretion: once an online content sharing platform falls within the scope of the Directive, the Article 17 regime applies.

This raises the question, why the enforcement of copyright-protected works requires less safeguards to be reconciled with conflicting fundamental rights. Besides a political reality, which is outside our scope, a simple answer at hand is that limitations and exceptions, which are to be respected by and partly harmonized by the Directive, are already an expression of that internalized balancing of conflicting fundamental rights. Or put differently: in a copyrightspecific context, limitations and exceptions are the 'only' tool for finding a fair balance between conflicting fundamental rights. And this, indeed, is in line with the Court of Justice's case law confirmed in Pelham, Funke Medien and Spiegel Online on these 'user rights' and the extent to which fundamental rights can (not) be invoked as external limitations to copyright.

On a more granular level, a second aspect relates to the importance of procedural safeguards in the Article 17-regime. If procedural safeguards in itself are relied upon as a weight in the balancing of fundamental rights as described above, the 'default'-scale is leaning towards right holders' protection: users are, in a way, awarded a secondary procedural protection in an attempt to find a new equilibrium. As Frosio notes, 'the introduction of a complaint and redress mechanism turns a traditionally $e x$ ante review mechanism into an ex post mechanism while content is taken down proactively regardless of the fairness of the use of the protected content, the application of exceptions or limitations or the public domain status of the works. ${ }^{76}$ But then, non-derogatory user rights and procedural safeguards -undoubtedly a good intention and a strengthening in itself- are hardly more than a drop in the bucket. If in the context of Article 17(4) DSM Directive, indeed, over-enforcement is unavoidable, the system comes with great legal uncertainty and wiggle room in practice. Article 17 DSM Directive constitutes a change of perspective from alleged under-enforcement copyright-protected works in certain situations, to a situation where over-enforcement via algorithmic content enforcement is deemed acceptable given safeguards (limitations and exceptions and procedural). So, what is left of user rights?

According to the DSM Directive, Member States shall ensure that users are able to rely on the exceptions and limitations, see Article 17(7). Also, the Directive shall 'in no way affect legitimate uses' and platforms shall inform users that they can use works under limitations and exceptions, see Article 17(9). In this way, the DSM Directive provides users with procedural safeguards. It is, however, far from clear how users should enforce their rights under the Directive. The DSM Directive does not specify the legal consequences of a platform's failure to live up to its obligations to ensure user rights. This stands in stark contrast to the situation of rights holders, where both international and EU legislation have boosted enforcement during the past many years. The TRIPS agreement ${ }^{77}$, for instance, devotes a full part (No. III) to the 'Enforcement of IPR', which obliges members to ensure that enforcement procedures are available to permit effective action against any act of infringement of IPRs. In the same vein, the

\footnotetext{
${ }^{76}$ Giancarlo Frosio, Reforming the C-DSM Reform: A User-Based Copyright Theory for Commonplace Creativity, (7 November 2019), https://ssrn.com/abstract=3482523, p. 17.

77 Trade Related Aspects of Intellectual Property Rights, available at https://www.wto.org/english/docs_e/legal_e/27-trips_03_e.htm.
} 
- DRAFT DECEMBER 2019

Forthcoming in Paul Torremans (ed), Intellectual Property Law and Human Rights, $4^{\text {th }}$ edition (Wolters Kluwer, 2020)

Enforcement Directive ${ }^{78}$ explains that effective and harmonized enforcement mechanisms are necessary to ensure that the substantive law on IP is applied effectively in the community. ${ }^{79}$

Against this background, it is remarkable that the DSM Directive does not attempt to ensure that the user rights, which arise under the limitations and exceptions regarding quotation, criticism, review, caricature, parody or pastiche are not backed up with enforcement tools ad modum those found in the Enforcement Directive. As seen in the light of the system set up by the DSM Directive and the general 'tilting of the balance' (as per Elkin-Koren) in favour of rights holders, the lack of attention to the enforcement of the rights and interests of users undermine not just the effects of the limitations and exceptions. It also serves as a reminder that no rights are worth more than the level to which they can be enforced. The DSM Directive may have provided users with strong 'rights' but without matching duties for platforms or a harmonised system for the enforcement of those user rights.

\footnotetext{
${ }^{78}$ Corrigendum to Directive 2004/48/EC of the European Parliament and of the Council of 29 April 2004 on the enforcement of intellectual property rights, (2004) OJ L 195, pp. 16-25.

${ }^{79}$ Ibid., Preamble point 3.
} 